\title{
PENGARUH BAP (BENZIL ADENIN PURIN) DAN NAA (NAPHTHALEN ACETIC ACID) TERHADAP EKSPLAN TANAMAN TURI (Sesbania grandiflora) DALAM MEDIA MULTIPLIKASI In Vitro
}

\author{
Mardhiyetti ${ }^{1}$, Zulfadli Syarif ${ }^{2}$, Novirman Jamarun ${ }^{1}$, Irfan Suliansyah ${ }^{2}$ \\ 1 Fakultas Peternakan, Universitas Andalas \\ 2 Fakultas Pertanian, Universitas Andalas \\ Email: Mardhiyetti@yahoo.com
}

\begin{abstract}
ABSTRAK
Turi merupakan leguminosa pohon. Perbanyakan turi secara vegetatif sulit dilakukan karena kemampuan turi untuk tumbuh kembali setelah dilakukan pemotongan sangat rendah. Penelitian dalam upaya perbanyakan turi melalui metode multiplikasi tanaman turi secara in vitro telah dilakukan di Laboratorium Kultur Jaringan. Eksplan yang digunakan adalah kotiledon, daun dan hipokotil steril tanaman turi. Media dasar yang digunakan adalah MS (Murashige skoog) yang diperkaya dengan vitamin. Sebagai sumber energi digunakan sukrosa sebanyak $30 \mathrm{~g} / \mathrm{l}$ dan bacto agar 8g/l. Penelitian ini terdiri dari perlakuan BAP sebagai salah satu jenis sitokinin) secara tunggal yaitu MS + BAP $1 \mathrm{mg} / \mathrm{l}$ dan MS + BAP $2 \mathrm{mg} / \mathrm{l}$, dan kombinas BAP dengan NAA (sebagai salah satu jenis auksin) yaitu MS + BAP 1mg/l + NAA o,08 mg/l, MS + BAP 2 mg/l + NAA o,o8 mg/l. Hasil penelitian menunjukkan bahwa kombinasi auksin dan sitokinin mampu memperbanyak shootled turi.
\end{abstract}

\section{Kata kunci: turi, ksplan, Benzil Adenin Purin, Naphthalen acetic acid, in vitro}

\section{PENDAHULUAN}

Turi merupakan tanaman hijau yang sangat berpotensi sebagai pakan ternak. Hal ini karena turi memiliki kandungan protein kasar yang tinggi dan semua bagian dari turi dapat bermanfaat untuk pakan ternak. Menurut hasil penelitian Siregar (1992) turi memiliki kandungan protein kasar tertinggi dibandingkan dengan beberapa bahan pakan ternak sejenis seperti kaliandra (Caliandra calothyrsus), lamtoro (Leucaena leucepala), gamal (Gliricidia maculate) dan beberapa jenis rumput lainnya. Menurut Sutikno (2002) bahwa turi merupakan salah satu leguminosa pohon golongan kacang-kacangan yang cukup berharga bila dikembangkan karena hampir semua bagian tanaman dapat dimanfaatkan sebagai bahan pakan. Pernyataan ini juga didukung oleh Heyna (1987). NAS (1979) menyatakan bahwa tidak ada faktor pembatas dalam penggunaan turi.

Sampai saat ini belum banyak informasi yang terungkap tentang pemanfatan dan budidaya turi secara optimal serta umur tanaman yang bisa dijadikan sebagai pakan ternak. Permasalahan mendasar lainnya adalah turi tidak dapat tumbuh kembali setelah dipotong, sehingga turi sangat sulit diperbanyak secara konvensional melalui stek. John dan Mannetje (1992) menyatakan bahwa respon tanaman turi untuk tumbuh kembali setelah ternak digembalakan atau terhadap pemupukan belum didapatkan informasinya. Oleh karena itu perlu dicari alternatif pemecahan masalah pengadaan bibit turi supaya turi selalu dapat dikembangkan.

Permasalahan di atas dapat dilakukan dengan perbanyakan secara in vitro, penggunaan teknik in vitro dengan metode kultur jaringan, akan mengatasi kendala-kendala yang umum dijumpai pada teknikteknik budidaya dengan pembiakan generatif ataupun vegetatif yang dapat dikatakan sebagai teknik konvensional. Menurut Suliansyah (2013) salah satu kelebihan perbanyak in vitro adalah mampu menghasilkan klon tanaman yang secara konvensional sulit diperbanyak secara vegetatif. Metode kultur jaringan merupakan salah satu teknik perbanyakan secara in vitro, perbanyakan in vitro bertujuan untuk menghasilkan tanaman baru dalam jumlah yang besar dan dalam waktu yang relatif singkat serta dapat dilakukan kapan saja (Gunawan, 1998).

Keberhasilan awal dari kultur jaringan menurut Primrose dan Old (1989) menyatakan bahwa agar diperoleh kultur jaringan tumbuhan yang berhasil, yang paling baik adalah memulai dengan suatu eksplan yang kaya akan sel-sel yang belum ditetapkan, misalnya yang berasal dari meristem karena sel-sel semacam itu mampu berploriferasi cepat, eksplan-eksplan yang biasa adalah pucuk, ujung akar, segmen buku atau biji yang sedang berkecambah. Eksplan yang digunakan berasal dari jaringan muda karena lebih sering berhasil karena sel-selnya masih aktif membelah, dinding selnya masih tipis, belum terjadi penebalan lignin dan sellulosa yang menyebabkan kekakuan pada sel. Gunawan (1995) menyatakan bahwa bagian tanaman yang dapat digunakan adalah: pucuk muda, batang muda, daun muda, kotiledon, dan hipokotil. Menurut Wattimena (1992) perbedaan dari bagian tanaman yang digunakan akan menghasilkan pola pertumbuhan yang berbeda. Eksplan tanaman yang masih muda 
menghasilkan tunas maupun akar adventif lebih cepat bila dibandingkan sengan bagin yang tua.

Disamping pemilihan jaringan yang tepat sebagai sumber eksplan, keberhasilan suatu kultur jaringan sangat tergantung pada nutrisi dan senyawasenyawa kimia yang terkandung pada suatu jenis medium, disamping zat pengatur tumbuh (ZPT) yang ditambahkan ke dalam media tersebut. ZPT mempunyai peranan penting dalam pertumbuhan dan perkembangan kultur. Faktor yang perlu mendapatkan perhatian dan penggunaan ZPT antara lain: 1) ZPT yang digunakan; 2) konsentrasi; 3) urutan penggunaan; 4) periode masa induksi dalam kultur tertentu. Auksin secara luas dalam kultur jaringan merangsang pertumbuhan kalus, suspensi sel dan organ. Pemilihan jenis auksin dan kosentrasi tergantung dari: 1) tipe pertumbuhan yang dikehendaki; 2) level auksin endogen; 3) kemampuan jaringan mensitesa auksin; 4) golongan zat tumbuh lain yang ditambahkan (Gunawan, 1995).

Zat pengatur tumbuh pada tanaman adalah senyawa organik yang bukan hara yang dalam jumlah sedikit dapat mendukung (promoye), menghambat dan merubah proses fisiologi tumbuhan (Abidin, 1995). Auksin dan sitokinin adalah zat pengatur tumbuh yang sering ditambahkan dalam media tanam karena mempengaruhi pertumbuhan dan organogenesis dalam kultur jaringan dan organ. Menurut Wattimena (1992) auksin sintetik perlu ditambahkan karen auksin yang terbentuk secara alami sering tidak mencukupi untuk pertumbuhan jaringan eksplan. Auksin mempunyai peranan terhadap pertumbuhan sel, dominasi apikal dan pembentukan kalus. Kisaran konsentrasi auksin yang biasa digunakan adalah 0,01-10 ppm.

Naphthalene Acetic Acid (NAA) adalah auksin sintetik yang sering ditabahkan dalam media tanam karena mempunyai sifat lebih stabil daripada jenis auksin lainnya seperti Indol Acetic Acid (IAA). Menurut Hendaryono dan Wijayani (1994), IAA dapat mengalami degradasi yang disebabkan adanya cahaya dan enzim oksidatif. Oleh karena sifatnya yang labil IAA jarang digunakan dan hanya merupakan hormon alami yang ada pada jaringan tanaman yang digunakan sebagai eksplan. Sedangkan NAA tidak mudah terurai oleh enzim yang dikeluarkan sel atau pemanasan pada proses sterilisasi. Sitokinin yaitu BAP adalah zat pengatur tumbuh yang berperan dalam mengatur pembelahan sel serta mempengaruhi diferensiasi tunas pada jaringan kalus. Penambahan auksin dan sitokinin secara kombinasi telah berhasil dilakukan terhadap beberapa spesies tanaman.

Berdasarkan kebutuhan zat pengatur tumbuh untuk pembentukan tunas maka dalam media perlu ditambahkan auksin dan sitokinin. Interaksi kedua zat ini mempengaruhi pertumbuhan morfologi dalam kultur sel, kultur jaringan dan organ. Konsentrasi dari kedua zat pengatur tumbuh ini sering mengendalikan bentuk dan jumlah pertumbuhan suatu kultur, baik pertumbuhan kalus atau organogenesis. Dari uraian diatas, perlu dilakukan penelitian yang bertujuan untuk mengetahui pengaruh BAP dan NAA terhadap kotiledon, daun, dan hipokotil pada media multiplikasi secara in vitro.

\section{MATERI DAN METODE}

\section{Materi}

Untuk penelitian ini sebagai sumber eksplan adalah kotiledon, daun, dan hipokotil, hasil perkecambahan biji secara in vitro. Bahan kimia penyusun media nutrisi dasar adalah media murashige skoog yang diperkaya dengan dengan vitamin). Zat pengatur tumbuh yang digunakan adalah Butiric Acetic Purin (BAP) dan l-Napthalenacetic Acid (NAA). Sebagai sumber energi digunakan sukrosa sebanyak $30 \mathrm{~g} / \mathrm{l}$ dan media dibuat padat dengan penambahan bacto agar sebanyak $8 \mathrm{~g} / \mathrm{l}$. pH media diatur hingga mencapai 5,8 dengan penambahan $\mathrm{HCL}$ atau $\mathrm{NaOH}$.

\section{Perlakuan dan Pengamatan}

Pengamatan dilakukan secara deskriptif, pada perlakuan dikelompokkan menjadi 4 bagian. Setiap kelompok terdiri atas 25 eksplan yang ditanam dalam 5 botol kultur, setiap botol kultur berisi 5 eksplan. Pemberian perlakuan pada masing-masing kelompok adalah sebagai berikut:

Perlakuan I : eksplan ditanam pada media MS + $1 \mathrm{mg} / \mathrm{l} \mathrm{BAP}$

Perlakuan II : eksplan ditanam pada media MS + $2 \mathrm{mg} / \mathrm{l} \mathrm{BAP}$

Perlakuan III: eksplan ditanam pada media MS + $1 \mathrm{mg} / \mathrm{l} \mathrm{BAP}+0,08 \mathrm{mg} / \mathrm{l} \mathrm{NAA}$

Perlakuan IV: eksplan ditanam pada media MS + $2 \mathrm{mg} / \mathrm{l} \mathrm{BAP}+0,08 \mathrm{mg} / \mathrm{l} \mathrm{NAA}$

Tahapan kerja dalam penelitian ini adalah alat-alat dan bahan yang akan digunakan disterilkan dengan menggunakan autoclaf pada suhu $121^{\circ} \mathrm{C}$ tekanan 15 psi selama 15 menit. Biji sebagai sumber eksplan disterilkan dengan bayclin, alkohol, aquades steril secara bertingkat sambil diaduk selama 10' kemudian disimpan dalam inkubasi selama 2 minggu. Media kecambah dan media perlakukan yang sudah disterilkan dituang sebanyak $20 \mathrm{ml}$ kemudian ditutup dengan aluminium foil dan selanjutnya disterilkan dengan autoklaf.

Kotiledon, daun, dan hipokotil yang muncul dipotong $(0,5 \mathrm{~cm})$ secara aseptic kemudian ditanam pada media perlakuan yang sudah dilengkapi dengan NAA dan BAP. Penanaman dilakukan di Laminar Air Flow Cabinet (LAFC). Kultur diinkubasi di dalam ruang pada suhu $24 \pm \pm^{\circ} \mathrm{C}$. Setiap 2 minggu sekali kultur dipindah pada medium yang sama dan diamati perkembangannya. Pengamatan terhadap jumlah tunas, warna kalus dan tekstur kalus dilakukan pada akhir penelitian.

\section{HASIL DAN PEMBAHASAN}

Pemberian BAP dan NAA pada media MS memberikan respon terhadap eksplan turi, eksplan 
Tabel 1. Warna kalus eksplan pada media multiplikasi

\begin{tabular}{llll}
\hline \multicolumn{1}{c}{ Perlakuan } & \multicolumn{1}{c}{ Kotiledon } & Daun \\
\hline MS +BAP $1 \mathrm{mg} / \mathrm{l}$ & Putih/tak berwarna & Putih/tak berwarna & Putih/tak berwarna \\
MS +BAP $2 \mathrm{mg} / \mathrm{l}$ & Putih/tak berwarna & Putih/tak berwarna & Putih/tak berwarna \\
MS+BAP1mg/l + NAA0,08mg/l & Putih/tak berwarna & Putih/tak berwarna & Putih kehijauan \\
MS+BAP2mg/l + NAA0,08mg/l & Putih/tak berwarna & Putih/tak berwarna & Putih kehijauan
\end{tabular}

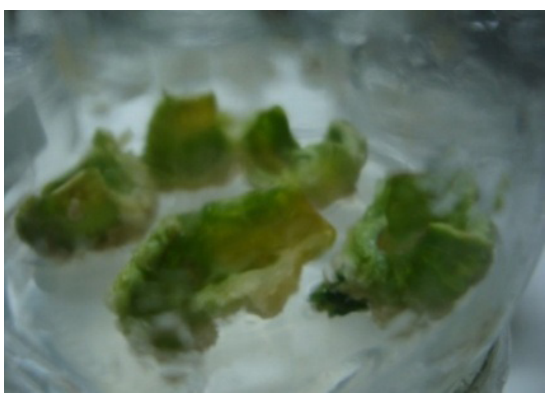

Kotiledon

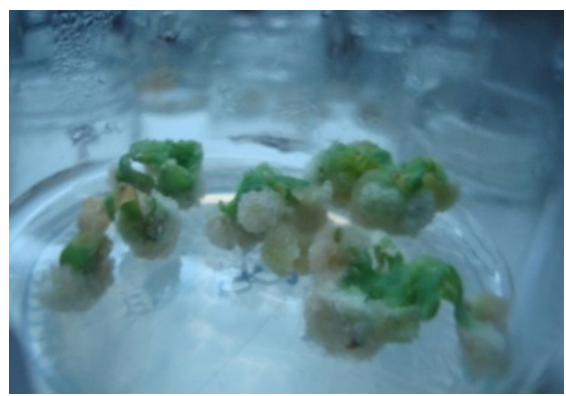

Daun

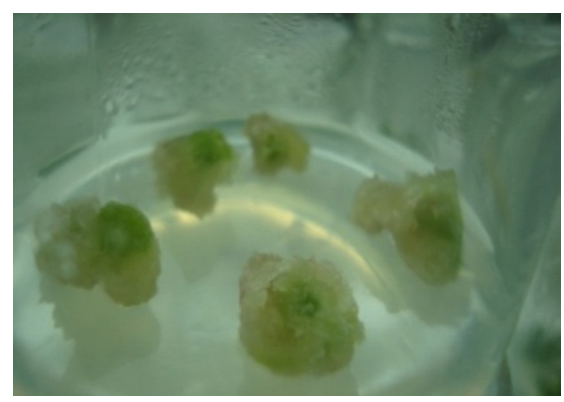

Hipokotil

Gambar 1. Tekstur dan warna kalus eksplan pada 3 minggu setelah tanam

dapat tumbuh dan berkembang pada media perlakuan. Respon masing-masing eksplan dapat dilihat pada Tabel 1.

Pada Tabel 1 terlihat bahwa perlakuan BAP tunggal maupun dikombinasikan dengan NAA dapat membentuk kalus dan memberikan respon terhadap warna kalus eksplan. Terbentuknya kalus pada eksplan disebabkan unsur-unsur hara yang terdapat dalam media MS mampu untuk menginduksi terbentuknya kalus. Kalus yang terbentuk berwarna putih pada kotiledon dan daun, sedangkan pada hipokotil didapatkan warna kalus putih kehijauan. Dari hasil yang diperoleh menunjukkan bahwa pada hipokotil bersifat organogenik (Gambar 1).

Tabel 2. Tekstur kalus eksplan pada media multiplikasi

\begin{tabular}{|c|c|c|c|}
\hline Perlakuan & Kotiledon & Daun & Hipokotil \\
\hline $\mathrm{MS}+\mathrm{BAP} 1 \mathrm{mg} / \mathrm{l}$ & Kompak & Kompak & $\begin{array}{c}\text { Kompak agak } \\
\text { ramah }\end{array}$ \\
\hline $\mathrm{MS}+\mathrm{BAP} 2 \mathrm{mg} / \mathrm{l}$ & Kompak & Kompak & $\begin{array}{c}\text { Kompak agak } \\
\text { remah }\end{array}$ \\
\hline $\begin{array}{l}\mathrm{MS}+\mathrm{BAP} 1 \mathrm{mg} / \mathrm{l}+ \\
\text { NAA } 0,08 \mathrm{mg} / \mathrm{l}\end{array}$ & Kompak & Kompak & $\begin{array}{c}\text { Kompak agak } \\
\text { remah }\end{array}$ \\
\hline $\begin{array}{l}\text { MS + BAP } 2 \mathrm{mg} / \mathrm{l}+ \\
\text { NAA 0,08 mg/l }\end{array}$ & Kompak & Kompak & $\begin{array}{c}\text { Kompak agak } \\
\text { remah }\end{array}$ \\
\hline
\end{tabular}

Tekstur kalus pada media multiplikasi dapat dilihat pada Tabel 2. Pada kotiledon dan daun tekstur kalus yang terbentuk kompak, sedangkan pada hipokotil kompak agak remah (Gambar 1). Kompak atau remahnya tekstur kalus sangat menentukan mudah atau sulitnya menginduksi tunas. Tekstur remah akan memudahkan antar sel untuk dipisahkan. Menurut Wattimena (1992) bahwa zat pengatur tumbuh adalah salah satu faktor yang penting diantara faktor lainnya yang dapat mempengaruhi pertumbuhan organ dari potongan jaringan yang ditanam baik jenis maupun konsentrasinya.
Tabel 3. Rata-rata hari inisiasi kalus pada media multiplikasi

\begin{tabular}{lccc}
\hline \multicolumn{1}{c}{ Perlakuan } & Kotiledon & Daun & Hipokotil \\
\hline MS + BAP $1 \mathrm{mg} / \mathrm{l}$ & - & - & - \\
MS + BAP 2 mg/l & - & - & - \\
MS + BAP $1 \mathrm{mg} / \mathrm{l}+$ NAA $0,08 \mathrm{mg} / \mathrm{l}$ & 21 & 11 & 4 \\
MS + BAP 2 mg/l + NAA 0,08 mg/l & 19 & 10 & 4 \\
\hline
\end{tabular}

Pada Tabel 3 menunjukkan hari inisiasi kalus tercepat pada hipokotil yaitu pada hari ke-4, berikutnya daun 10 hari dan kotiledon 19 hari. Pada hipokotil kalus yang terbentuk lebih cepat dengan warna kalus kompak remah, namun pencoklatan cepat terjadi (Gambar 1). Untuk memperbanyak jumlah shoodlet yang dihasilkan diperlukan media multiplikasi, pada Tabel 4. Terlihat bahwa pemberian Sitokinin tunggal belum memperlihatkan respon eksplan yang tepat. Sedangkan dengan pemberian kombinasi auksin dan sitokinin, jumlah shoodlet dapat ditingkatkan. Menurut Gunawan (1995) salah satu faktor yang menentukan keberhasilan suatu kultur jaringan adalah kombinasi dan konsentrasi zat pengatur tumbuh yang diberikan.

Tabel 4 . Rata-rata jumlah tunas pada eksplan yang berbeda pada media multiplikasi (\%)

\begin{tabular}{lccc}
\hline \multicolumn{1}{c}{ Perlakuan } & Kotiledon & Daun & Hipokotil \\
\hline MS + BAP $1 \mathrm{mg} / \mathrm{l}$ & - & - & - \\
MS + BAP $2 \mathrm{mg} / \mathrm{l}$ & - & - & - \\
MS + BAP $1 \mathrm{mg} / \mathrm{I}+$ NAA $0,08 \mathrm{mg} / \mathrm{l}$ & 1,8 & - & 1,2 \\
MS + BAP $2 \mathrm{mg} / \mathrm{l}+$ NAA $0,08 \mathrm{mg} / \mathrm{l}$ & 5,3 & - & 2,5 \\
\hline
\end{tabular}

Media multiplikasi yang digunakan pada beberapa eksplan turi memberikan respon yng berbeda-beda. Pada kotiledon dengan media perlakuan tunggal yaitu sitokinin BAP $1 \mathrm{mg} / \mathrm{l}$ dan $2 \mathrm{mg} / \mathrm{l}$ tidak mampu memberikan respon terhadap jumlah shootled, walaupun penggunaan BAP umum digunakan untuk induksi dan multiplikasi tunas namun pada turi pemberian zat pengatur tumbuh ini dengan pemberian tunggal belum mampu merangsang sel-sel untuk berdiferensiasi membentuk shootled (Gambar 2). 


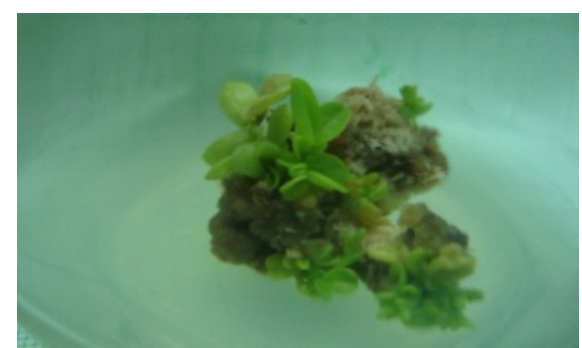

Kotiledon

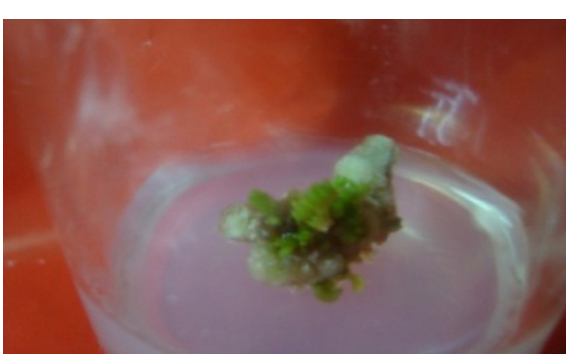

Daun

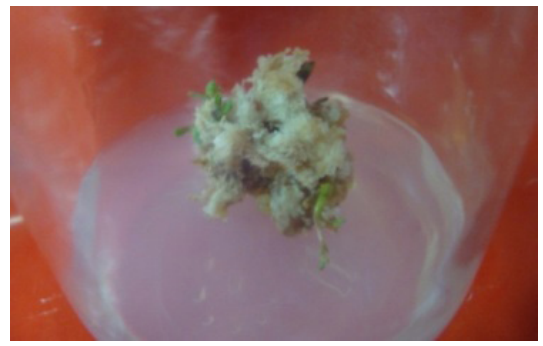

Hipokotil

Gambar 2. Jumlah tunas yang terbentuk pada eksplan

Menurut Wattimena (1992) perbedaan dari bagian yang digunakan akan menghasilkan pola pertumbuhan yang berbeda. Shaik (2009) menggunakan kotiledon lamtoro (Leucaena leucochepala) dalam media multiplikasi.

Aplikasi zat pengatur tumbuh dengan pemberian kombinasi yaitu BAP $1 \mathrm{mg} / \mathrm{l}+\mathrm{NAA} 0,08 \mathrm{mg} / \mathrm{l}$ dan BAP $2 \mathrm{mg} / \mathrm{l}+$ NAAo.08 mg/l mampu membentuk shootled, disini dapat dilihat bahwa proses induksi tunas untuk turi membutuhkan keseimbangan antara auksin dan sitokinin, terjadinya peningkatan jumlah tunas pada pemberian BAP $2 \mathrm{mg} / \mathrm{l}+\mathrm{NAA} 0,08 \mathrm{mg} / \mathrm{l}$ tidak diikuti dengan pemanjangan batang. Hasil penelitian Sofia (2007) menunjukkan bahwa induksi tunas pada tanaman kedelai menghasilkan tunas terbanyak pada BAP $2 \mathrm{mg} / \mathrm{l}$ yang dikombinasikan dengan CCC.

\section{SIMPULAN}

Pemberian NAA dan BAP dapat meningkatkan jumlah tunas pada media multiplikasi. Metode multiplikasi shootled turi yang didapatkan dalam penelitian ini dapat dijadikan acuan untuk penelitian selanjutnya pada media regenerasi. Tahapan berikutnya diperlukan penelitian untuk mendapatkan media untuk menginduksi akar.

\section{DAFTAR PUSTAKA}

Gunawan, L. W. 1995. Teknik Kultur Invitro Dalam Hortikultura. Penebar Swadaya. Jakarta

Hendaryono, D.P.S dan A. Wijayani.1994. Teknik Kultur Jaringan. Kanisius. Yogyakarta.

NAS. 1979. Forages. National Academy of Sciences. Washington, DC.

Primrose. S. B. dan Old. R. W. 1996. Prinsip-prinsip Manipulasi Gen. Suatu Pengantar Rekayasa Genetik. OXFORD. London.

Shaik, N. M, 2009. Improved Method of In Vitro Regeneration in Leucaena lecocephala-a leguminous Pulpwood Tree Species. Ind. J. Bio-Plant 15:312-318.

Siregar, S. B. 1992. Ransum Ternak Ruminasia . Pusat Penelitian dan Pengembangan Peternakan Bogor.

Sutikno, I. 2002. Pengolahan biji turi (sesbania grandiflora) untuk mengurangi senyawa anti nutrisi. Balai Penelitian Ternak. Bogor.

Sofia, D. 2007. Pengaruh Berbagai Konsentrasi Benzyl Amino Purine dan Cycocel Terhadap Pertumbuhan Embrio Kedelai (Glycine Max L. Merr.) Secara In Vitro.Fak. Pertanian. USU.

Suliansyah, I. 2013. Kultur jaringan tanaman. LeutikaPrio. Yogyakarta.

Wattimena GA. 1992. Bioteknologi Tanaman. Volume ke - 1 . Bogor: Pusat Antar Universitas (PAU).Bioteknologi.Institut Pertanian Bogor. 